\title{
PERBAIKAN TANAH DASAR JALAN TOL SEMARANG - DEMAK MENGGUNAKAN BAHAN ADITIF DAN PERKUATAN KOLOM STABILISASI
}

\author{
Anindita Dwi Anggraini ${ }^{1}$, Ahmad Rifa' ${ }^{2}{ }^{2}$, Fikri Faris ${ }^{3}$ \\ ${ }^{1}$ Mahasiswa / Departemen Teknik Sipil dan Lingkungan / Universitas Gadjah Mada \\ 2,3 Dosen / Departemen Teknik Sipil dan Lingkungan / Universitas Gadjah Mada \\ Korespondensi: anindita.dwi.anggraini@gmail.com
}

\begin{abstract}
In Semarang there is often a flood of sea water that swamp the road. This happens because the ground is lower than the water level, load-carrying capacity is deficient. Following up on this, a new road network is needed as a toll road. To accomplish the problem, it is necessary to increase the load-carrying capacity by improve the subgrade on the toll road using additive and strengthen the stabilization column. Additives used in the form of additives made of inorganic materials containing compounds of calciumchloriddihydrat with pH of 8.24 which has ion bonding energy is greater than the metal material on the surface of the soil grains. The general composition consists of carbon elements $72.78 \%$, hydrogen $21.11 \%$, and nitrogen $1.36 \%$. The research was conducted on soil mix, additive material by comparison 1 gram of additive, 1 liter of water and variation of cement content like 4\%, 5\%, 6\%, 7\%. To get the optimum mix for soil improvement. Then numerical analysis by using Plaxis Software v.8.6 with variation of soil thickness and column length stabilization. Test results show that the soil is high-plasticity clay. The soil stabilization was eligible for soil compressive strength testing for layers of soil composite cement foundation of $24 \mathrm{~kg} / \mathrm{cm} 2$. Soil compressive strength testing of soil stabilization is $2,47 \mathrm{~kg} / \mathrm{cm}^{2}$ with $7 \%$ cement and addictive. Based on numerical analysis with plaxis $v 8.6$ software, the deformation value in the model with $5 \mathrm{~m}$ thick soil stabilization and $50 \mathrm{~m}$ stabilization column length has met the embankment degression limit according to the PU guideline that is $20 \mathrm{~mm}$ for the 1st class road. For the value of road stability safety factor, eligible value 1.4.
\end{abstract}

Keywords : additive, embankment, plaxis, soil deformation, stabilization column

\section{PENDAHULUAN}

Ruas jalan Semarang - Demak sering terjadi banjir air laut atau naiknya permukaan air laut yang menggenangi jalan. Permasalahan ini terjadi di daerah yang muka tanah lebih rendah dari muka air, dimana tanah memiliki daya dukung yang kurang baik. Menindak lanjuti masalah tersebut, diperlukan suatu jaringan jalan baru yang berfungsi sebagai jalan tol agar sistem transportasi dapat efektif dan efisien.

Untuk menangani permasalahan yang terjadi, perlu upaya peningkatan daya dukung tanah. Salah satu metode untuk meningkatkan daya dukung tanah dengan melakukan perbaikan tanah dasar pada jalan tol menggunakan bahan aditif dan perkuatan kolom stabilisasi. Bahan aditif yang digunakan berupa bahan aditif yang terbuat dari material anorganik yang mengandung senyawa calsiumchloriddihydrat dengan $\mathrm{pH} 8,24$ yang memiliki energi ikatan ion yang lebih besar dari pada materi logam pada permukaan butiran tanah. Komposisi umum terdiri dari unsur Carbon 72,78\%, Hidrogen 4,75\%, Oksigen 21,11\% dan Nitrogen 1,36\%.

Penelitian difokuskan pada pengujian campuran tanah, bahan aditif dengan perbandingan 1 gram bahan aditif : 1 liter air dan variasi kadar semen $4 \%, 5 \%, 6 \%, 7 \%$ dari berat kering tanah sehingga didapatkan campuran optimum. Parameter yang digunakan adalah nilai Unconfined Compression Strength, dengan lama pemeraman 7 dan 14 hari. Kemudian dilakukan analisis numeris menggunakan Software Plaxis v.8.6 dengan variasi tebal tanah stabilisasi dan variasi 
panjang kolom stabilisasi. Tujuan dari penelitian ini adalah :

1. Mengetahui pengaruh campuran terhadap sifat teknis dan mekanis.

2. Mengetahui campuran optimum.

3. Mengetahui kestabilan timbunan jalan.

4. Menganalisis pengaruh tebal tanah stabilisasi dan panjang kolom stabilisasi terhadap deformasi timbunan jalan.

\section{TINJAUAN PUSTAKA}

\subsection{Tanah Lunak}

Tanah lunak mempunyai kuat geser rendah, kompresibilitas tinggi. kadar air tinggi, daya dukung rendah, stabilitas rendah, dan koefisien permeabilitas kecil. Tanah ini menyebabkan ketidakstabilan dan penurunan jangka panjang. Dalam praktek, perbaikan tanah dasar dilakukan pada tanah lunak.

\subsection{Tanah Dasar (Sugrade)}

Tanah dasar merupakan tanah yang terletak dipermukaan dasar dengan ketebalan tertentu yang dipadatkan [1]. Apabila tanah dasar terletak pada daerah timbunan, maka tanah diambil dari tempat pengambilan bahan timbunan yang dipadatkan dengan tingkat kepadatan tertentu, sehingga diperoleh daya dukung tanah dasar yang tinggi [2]. Tanpa dukungan yang cukup dari tanah dasar, maka struktur diatas tanah dasar akan mengalami kerusakan.

\subsection{Klasifikasi Tanah}

Klasifikasi tanah merupakan pemilihan tanah ke dalam kelompok sifat atau kelakuan yang sama untuk memperoleh karateristik tanah. Terdapat dua sistem klasifikasi yaitu :

1. Unified Soil Classification System (USCS) Pada sistem USCS tanah diklasifikasikan tanah berbutir kasar dan berbutir halus.

2. American Association of State Highway and Transportation Officials (AASHTO)

Pada sistem AASHTO berguna untuk menentukan kualitas tanah timbunan jalan, subbase dan subgrade.

Menurut Bowles [3], sistem klasifikasi tanah yang paling banyak dipakai (dan secara internasional) adalah sistem USCS.

\subsection{Lapis Pondasi Semen Komposit}

Lapis pondasi semen komposit tanah merupakan lapis pondasi dari tanah yang distabilkan dengan semen komposit. Ketentuan dapat dilihat pada Tabel 1. Semen komposit adalah semen portland standart yang dicampur dengan bahan tambah bubuk mineral tertentu [4]. Jenis semen yang digunakan semen portland type 1 .

Tabel 1. Lapis pondasi tanah semen

\begin{tabular}{lcc}
\hline \multirow{2}{*}{ Pengujian } & \multicolumn{2}{c}{ Batasan Sifat (Setelah Perawatan 7 Hari) } \\
\cline { 2 - 3 } & Min. & Maks. \\
\hline UCS, $\mathrm{kg} / \mathrm{cm}^{2}$ & 20 & 35 \\
SNI 03-6887-2002 & $2016)$
\end{tabular}

\subsection{Bahan Aditif}

Untuk meningkatkan kemampuan dan kinerja tanah serta merubah sifat-sifat teknis tanah maka tanah perlu dilakukan perbaikan tanah dengan menambahkan bahan aditif ke tanah dengan perbandingan campuran tertentu. Bahan aditif yang digunakan terbentuk dengan cara ion exchange yang berfungsi memadatkan, menstabilkan tanah dan memaksimalkan ikatan soil cement seperti pada Gambar 1. Bahan aditif ini merupakan material anorganik yang mengandung senyawa calsiumchloriddihydrat dengan $\mathrm{pH} 8,24$ yang memiliki energi ikatan ion yang lebih besar dari pada materi logam pada permukaan butiran tanah. Komposisi umum terdiri dari unsur Carbon 72,78\%, Hidrogen $4,75 \%$, Oksigen $21,11 \%$, dan Nitrogen $1,36 \%$. Prinsip kerja bahan aditif ini adalah menyisihkan materi yang berada pada permukaan tanah seperti lapisan air yang menghambat semen menjadi keras.

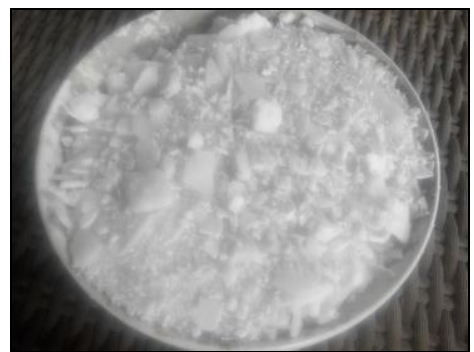

Gambar 1. Bahan aditif

\subsection{Deep Soil Mixing}

Deep Soil Mixing (DSM) adalah sebuah teknologi perbaikan tanah di lapangan secara langsung untuk memperbaiki sifat teknis tanah dan meningkatkan daya dukung tanah, dimana tanah dicampur dengan bahan semen, kapur, flyash, gypsum, bentonite dan/atau bahan lainnya [5]. Proses perbaikan tanah ini dapat dilakukan dalam bentuk kering dan bentuk cair. Deep soil mixing terbagi dalam dua kelompok yaitu column installation dan mass stabilization. Pada Gambar 2 dapat dilihat 
mekanisme penggunaan deep soil mixing. Pemasangan kolom dapat menggunakan single columns atau interlocking columns.

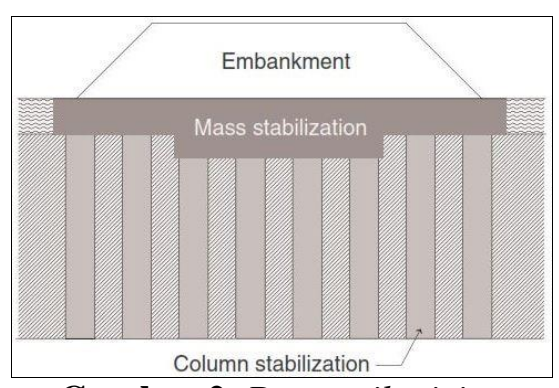

Gambar 2. Deep soil mixing

\subsection{Analisis Stabilitas Timbunan}

Pada umumnya stabilitas timbunan di atas tanah lunak dihitung menggunakan metode analisis tegangan total. Analisis ini cukup konservatif karena diasumsikan tidak terjadi peningkatan kekuatan pada tanah dasar. Prosedur perencanaan dengan menggunakan analisis tegangan total dianggap lebih sesuai dan lebih sederhana untuk perencanaan perkuatan timbunan.

\subsection{Faktor Keamanan Timbunan}

Faktor keamanan diperlukan untuk mengurangi resiko keruntuhan sampai dapat diterima timbunan. Waktu kritis stabilitas timbunan pada tanah lunak adalah selama dan segera setelah selesai pelaksanaan. Proses konsolidasi tanah lunak di bawah timbunan menyebabkan kuat geser tanah lunak meningkat. Faktor keamanan timbunan berdasarkan kelas jalan terdapat pada Tabel 2.

Tabel 2. Faktor keamanan timbunan

\begin{tabular}{cc}
\hline Kelas Jalan & Faktor Keamanan \\
\hline I \& II & 1,4 \\
III \& IV & 1,3 \\
\hline Sumber: Pusat Litbang Prasarana Transportasi (2005) [6]
\end{tabular}

\subsection{Faktor Kestabilan Timbunan \\ 2.9.1 Kuat Geser Tanah}

Kuat geser tanah merupakan momen gaya yang menahan massa tanah berada pada tempatnya untuk menjaga kestabilan [7]. Kekuatan geser massa tanah adalah perlawanan internal tanah per satuan luas terhadap keruntuhan [8]. Besarnya kuat geser massa tanah dikontrol oleh kohesi (c) dan sudut gesekan dalam antara partikel penyusun tanah $(\varphi)$.

\subsubsection{Tekanan Air Pori}

Rembesan air di dalam tanah menyebabkan gaya rembesan pada stabilitas tanah. Jika terjadi penurunan muka air tanah, maka terjadi pengurangan gaya angkat air pada massa tanah, yang dapat menambah beban. Kenaikan beban menyebabkan kenaikan tegangan geser, apabila tahanan geser tanah terlampaui akan mengakibatkan longsoran. Hal ini banyak terjadi pada tanah permeabilitas rendah [9].

\subsubsection{Kondisi Pembebanan}

Beban yang berpengaruh pada tanah terdiri dari beban internal yang berasal dari volume serta berat jenis tanah dan beban eksternal terdiri dari beban statis dan dinamis [10]. Pada analisis timbunan jalan, beban yang diperhitungkan adalah beban lalu lintas pada lebar permukaan timbunan jalan dan beban perkerasan jalan. Beban lalu lintas sesuai kelas jalan seperti pada Tabel 3.

Tabel 3. Beban lalu lintas

\begin{tabular}{cc}
\hline Kelas Jalan & Beban Lalu Lintas $(\mathrm{kPa})$ \\
\hline I & 15 \\
II & 12 \\
III & 12 \\
\hline Sumber: SNI 8460:2017 (2017) [11]
\end{tabular}

\subsection{Penurunan Timbunan}

Jika lapisan tanah dibebani, maka tanah akan mengalami penurunan atau regangan. Perhitungan penurunan terdiri dari perkiraan total penurunan yang terjadi dan kecepatan atau waktu untuk mencapai tingkat penurunan. Analisis dilakukan pada garis tengah dan pinggir atas timbunan. Batas penurunan timbunan terdapat pada Tabel 4.

Tabel 4. Batas penurunan untuk timbunan

\begin{tabular}{cc}
\hline Kelas Jalan & $\begin{array}{c}\text { Kecepatan Penurunan Setelah Konsolidasi } \\
(\mathrm{mm} / \text { tahun })\end{array}$ \\
\hline I & $<20$ \\
II & $<25$ \\
III & $<30$ \\
IV & $<30$ \\
\hline Sumber: Pusat Litbang Prasarana Transportasi (2005)[7]
\end{tabular}

\subsection{Plaxis 2D V.8.6.}

Plaxis merupakan program analisa geoteknik, untuk analisa stabilitas tanah sesuai prinsip metode elemen hingga yang mampu menganalisa mendekati perilaku sebenarnya [12]. Permodelan yang digunakan permodelan plane strain (regangan bidang).

\subsection{Model Material}

Model keruntuhan Mohr-Coulomb merupakan model keruntuhan material yang 
dianggap cukup mewakili perilaku tanah secara umum untuk menggambarkan kekuatan tanah. Menurut Rifa'i [13] model Mohr-Coulomb adalah elasto-plastic yang terdiri dari lima parameter yaitu $\mathrm{E}$ dan $\mathrm{v}$ untuk elastisitas tanah, c dan $\varphi$ untuk plastisitas tanah dan $\psi$ sebagai sudut dilatasi.

\section{METODOLOGI PENELITIAN}

\subsection{Lokasi Pengambilan Sampel}

Lokasi pengambilan sampel dilakukan di

Jalan Nasional Semarang-Demak yang dapat dilihat pada Gambar 3.

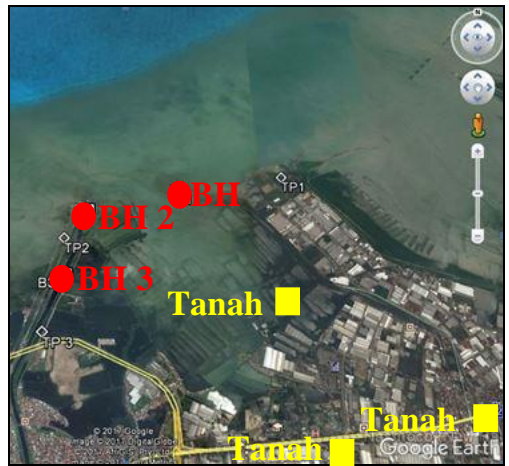

Gambar 3. Lokasi pengambilan sampel

\subsection{Bahan Penelitian}

ini adalah :

Bahan yang digunakan pada penelitian

1. Disturbed dan undisturbed sampel pada kedalaman 0,5 - $1 \mathrm{~m}$.

2. Semen PC (Portland Cement)

3. Bahan Aditif material anorganik

4. Air

\subsection{Data Penelitian}

Data penelitian yang digunakan pada penelitian ini adalah sebagai berikut:

1. Data Primer

Data primer didapatkan dari hasil survey dan investigasi lapangan. Setelah dilakukan survey dan investigasi lapangan, kemudian dilanjutkan dengan melakukan pengambilan sampel tanah dari tiga titik yang mewakili lokasi penelitian yang kemudian diuji dilaboratorium. Pengujian yang dilakukan di laboratorium diantaranya :

a. Kadar air tanah (ASTM D 2216-98).

b. Specific gravity (ASTM D 854-02).

c. Distribusi ukuran butir (ASTM D 1140-00 dan ASTM D 422-63).

d. Atteberg (ASTM D 4318-00 dan ASTM D 4318-00).

e. Berat volume tanah (ASTM C - 29).

f. Kuat tekan bebas (ASTM D 2166) g. CBR (ASTM D- 188373)

2. Data Sekunder

Data Sekunder didapatkan dari instansi terkait berupa data tanah hasil pengujian sondir dan bor $\log$ dari pengujian yang terdahulu.

\subsection{Variasi Pengujian}

Variasi pengujian pada penelitian ini dapat dilihat pada Tabel 5.

Tabel 5. Variasi pengujian di laboratorium

\begin{tabular}{cccc}
\hline No & Variasi Pengujian & Kadar Semen & Bahan Aditif \\
\hline 1 & Tanah + Semen & $4 \%, 5 \%$, & - \\
2 & Tanah + Semen & $6 \%, 7 \%$ & 1gr : 1 liter \\
& + Bahan Aditif & & air \\
\hline
\end{tabular}

\subsection{Tahapan Pengujian}

Pengujian tanah asli menggunakan undisturbed sampel untuk mengetahui sifat fisis dan mekanis tanah asli. Setelah itu dilanjutkan dengan pengujian tanah campuran (tanah stabilisasi). Proses mixing diawali dengan melarutkan bahan aditif kedalam air. Kemudian dicampurkan dengan berat kering tanah dan semen. Setelah itu, benda uji dibuat dengan ukuran tinggi $7 \mathrm{~cm}$ dan diameter $3,5 \mathrm{~cm}$ seperti yang terlihat pada Gambar 4. Lama pemeraman benda uji selama 7 hari dan 14 hari. Setelah diperam, benda uji dilakukan pengujian UCS dan braziliant test. Hasil dari pengujian tersebut, dapat diketahui campuran optimum untuk perbaikan tanah dasar. Parameter dari campuran optimum digunakan untuk anaisis numerik dalam permodelan mass stabilization dan kolom stabilisasi.

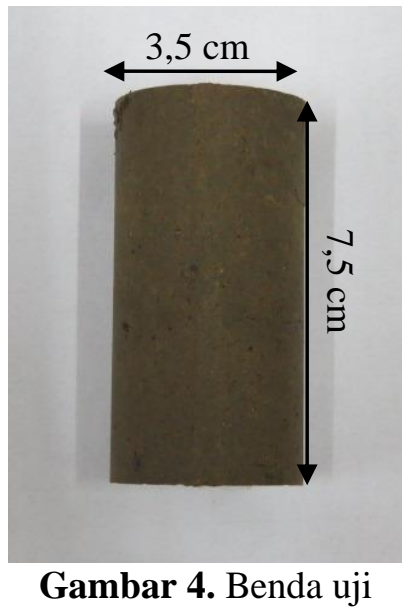

\subsection{Tahapan Pelaksanaan Penelitian}

Tahapan pelaksanan penelitian ditampilkan dalam bentuk bagan alir rencana penelitian pada Gambar 5. 


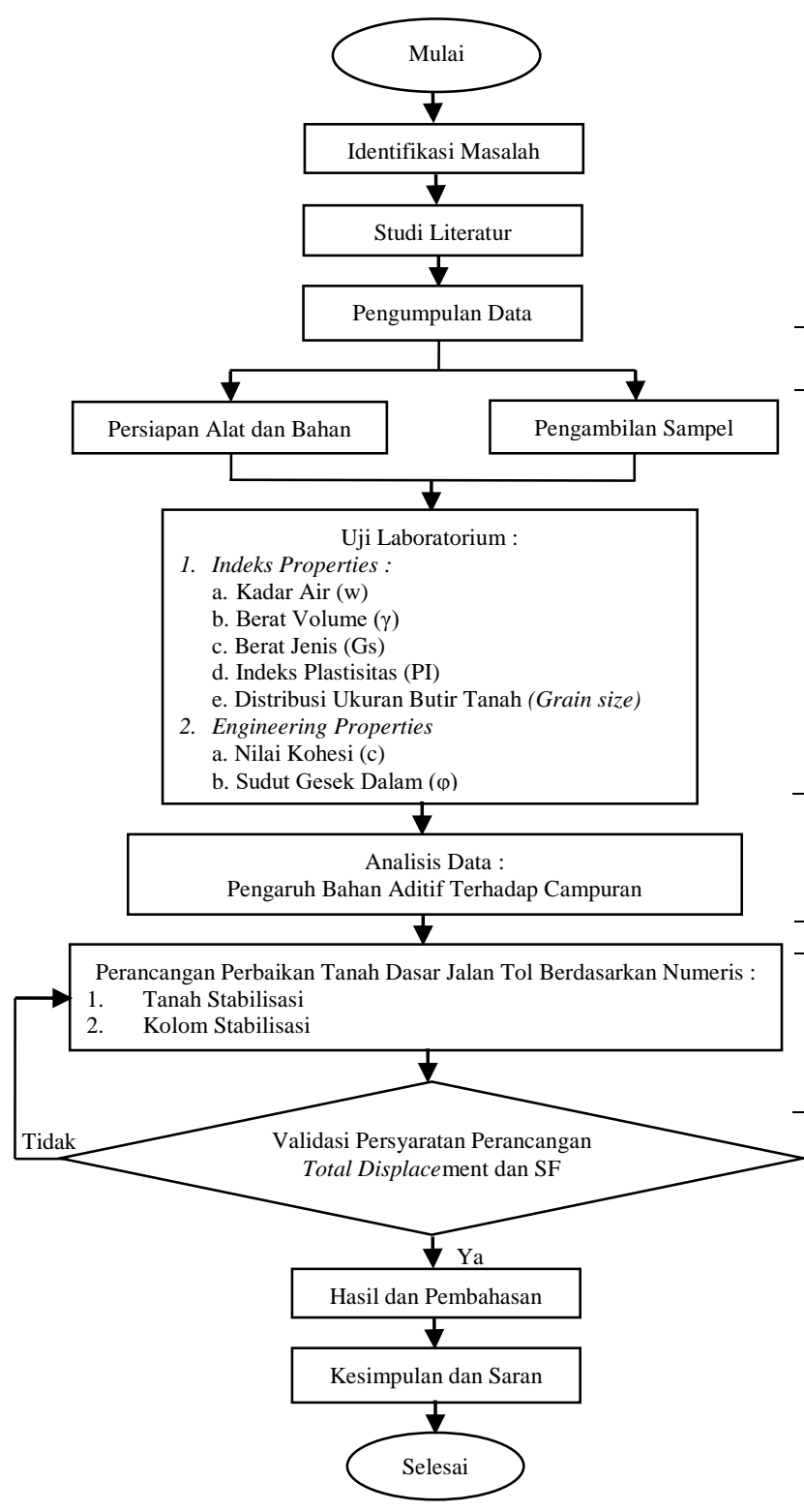

Gambar 5. Bagan air penelitian

\section{HASIL DAN PEMBAHASAN \\ 4.1 Sifat Teknis dan Mekanis}

Hasil pengujian sifat fisis tanah asli dapat dilihat pada Tabel 6. dan sifat mekanis tanah asli pada Tabel 7.

\subsection{Pengaruh Semen dan Bahan Aditif 4.2.1 Kepadatan Tanah}

Hasil kepadatan tanah optimum dapat dilihat pada Tabel 8. Pada pengujian kepadatan tanah, semakin besar penambahan kadar semen, maka semakin menurun kadar air optimum dan semakin meningkat berat volume kering tanah. Grafik hubungan tersebut dapat dilihat pada Gambar 6. Hasil berat volume kering campuran tanah, semen dan aditif lebih tinggi dari campuran tanah dan semen. Kadar air optimum campuran tanah, semen dan aditif lebih rendah dari campuran tanah dan semen. Grafik dapat dilihat pada Gambar 7 dan Gambar 8.

Tabel 6. Hasil pengujian sifat fisis tanah

\begin{tabular}{clcccc}
\hline \multirow{2}{*}{ No } & Parameter & Satuan & Tanah & Tanah & Tanah \\
& & & 2 & 3 \\
\hline 1 & Kadar air & $\%$ & 52,99 & 44,22 & 59,92 \\
2 & Berat jenis & - & 2,57 & 2,51 & 2,58 \\
3 & Tanah lolos & $\%$ & 93,49 & 99,54 & 96,58 \\
& No.40 & & & & \\
4 & Tanah lolos & $\%$ & 77,79 & 97,82 & 89,43 \\
5 & No.200 & $\%$ & 96,50 & 63,50 & 92,40 \\
6 & Batas cair & $\%$ & 33,67 & 27,43 & 35,45 \\
7 & Batas plastis & $\%$ & 12,55 & 19,76 & 16,13 \\
8 & Indeks plastis & $\%$ & 63,99 & 35,78 & 56,72 \\
9 & Klas. & & A-7-5 & A-7-6 & A-7-5 \\
10 & AASHTO & & CH & CH & CH \\
\hline
\end{tabular}

Tabel 7. Hasil pengujian sifat mekanis tanah

\begin{tabular}{clcccc}
\hline No & Parameter & Satuan & Tanah 1 & Tanah 2 & Tanah 3 \\
\hline 1 & OMC & $\%$ & 30,85 & 23,30 & 20,57 \\
2 & MDD & $\mathrm{gr} / \mathrm{cm}^{3}$ & 1,334 & 1,474 & 1,662 \\
3 & Kohesi & $\mathrm{kg} / \mathrm{cm}^{2}$ & 0,188 & 0,125 & 0,114 \\
4 & Sudut geser & $\circ$ & 0,08 & 3,71 & 2,07 \\
5 & Kuat tekan & $\mathrm{kg} / \mathrm{cm}^{2}$ & 0,11 & 0,05 & 0,06 \\
\hline
\end{tabular}

Tabel 8. Kepadatan tanah optimum

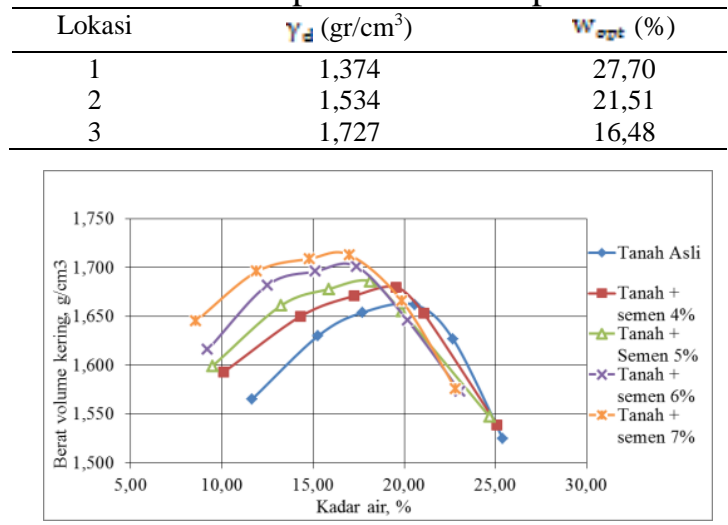

Gambar 6. Grafik kadar air dan berat kering

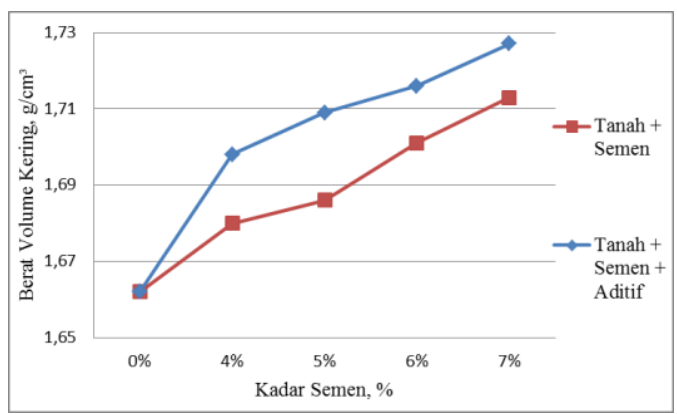

Gambar 7. Grafik berat volume kering 


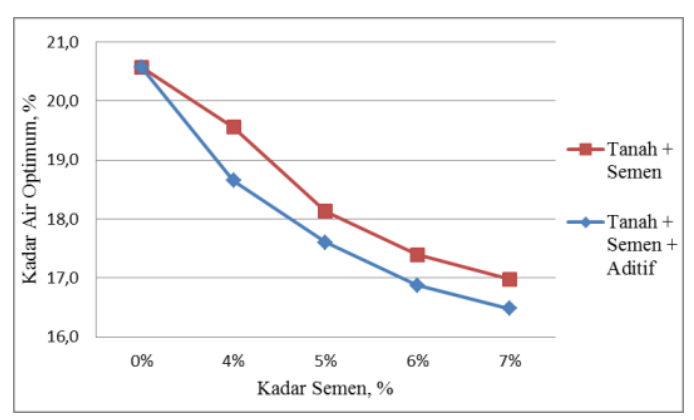

Gambar 8. Grafik kadar air optimum

\subsubsection{Kuat Tekan Tanah (UCS)}

Dalam penelitian ini, kriteria standart yang digunakan berdasarkan syarat pengujian kuat tekan tanah (nilai UCS) untuk lapis pondasi semen komposit tanah. Nilai kuat tekan tanah optimum pada tanah campuran adalah $2,47 \mathrm{~kg} / \mathrm{cm}^{2}$ dengan kadar semen $7 \%$ dan penambahan bahan aditif. Hasil pengujian tersebut belum memenuhi kriteria standart. Akan tetapi hasil pengujian kuat tekan tanah stabilisasi menunjukan peningkatan sampai 41,17 kali dari nilai kuat tekan tanah asli Peningkatan tersebut terjadi karena adanya pengaruh campuran kadar semen dan campuran kadar semen dengan bahan aditif. Peningkatan terjadi di semua lokasi. Pada Gambar 9 dapat dilihat grafik peningkatan kuat tekan pada lokasi 3.

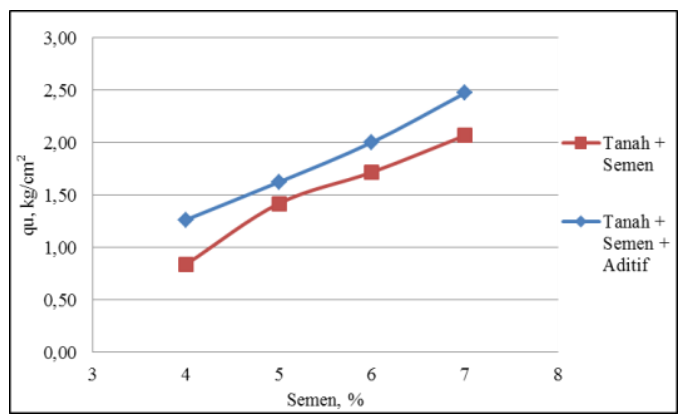

Gambar 9. Grafik kuat tekan

\subsubsection{Kohesi dan Sudut Geser Tanah}

Nilai kohesi didapatkan dari pengujian kuat tekan bebas sedangkan sudut geser didapatkan dari uji brazilliant. Dari hasil kuat tekan optimum didapatkan nilai kohesi sebesar $0,59 \mathrm{~kg} / \mathrm{cm}^{2}$ dan sudut geser sebesar $41,39^{\circ}$. Grafik peningkatan nilai kohesi dan nilai sudut geser dapat dilihat pada Gambar 10 dan Gambar 11.

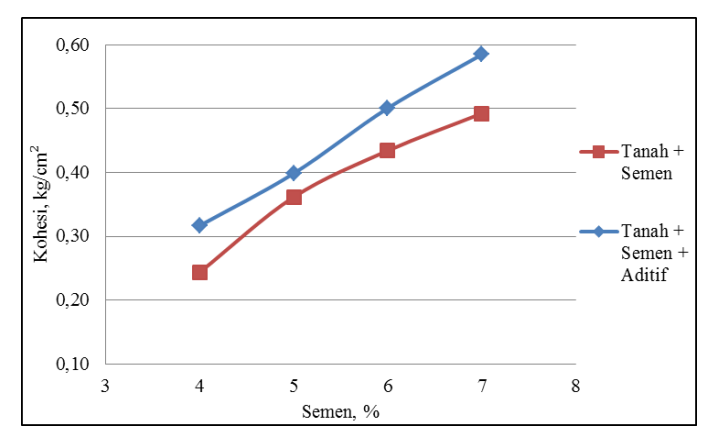

Gambar 9. Grafik kohesi

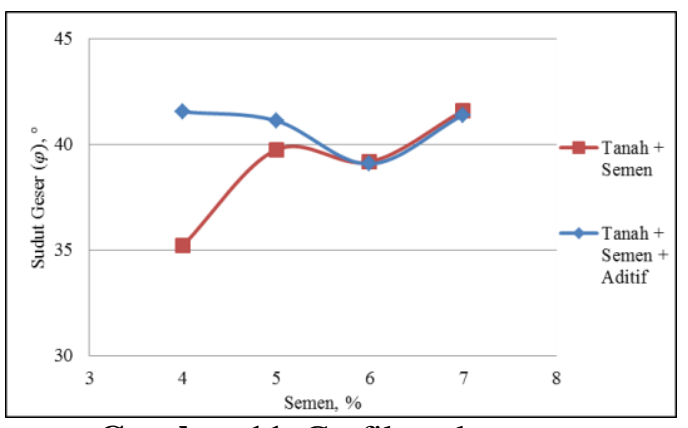

Gambar 11. Grafik sudut geser

\subsection{Analisis Numerik Model Timbunan \\ 4.3.1 Cross Section}

Dalam permodelan Plaxis perlu diketahui cross section tanah untuk mengetahui stratigrafi tanah. Untuk itu dibutuhkan data borlog. Cross section dapat dilihat pada Gambar 12. Untuk model material yang digunakan dalam penelitian ini adalah Mohr Coulomb. Parameter material tanah yang digunakan dalam analisis ini dapat dilihat pada Tabel 11 dan Tabel 12. Parameter tanah yang digunakan sebagai stratigrafi tanah seperti nilai parameter seperti $\mathrm{E}, \mathrm{v}, \mathrm{c}$ dan $\varphi$ didapatkan berdasrkan empiris, sedangkan parameter tanah stabilisasi didapatkan dari hasil pengujian.

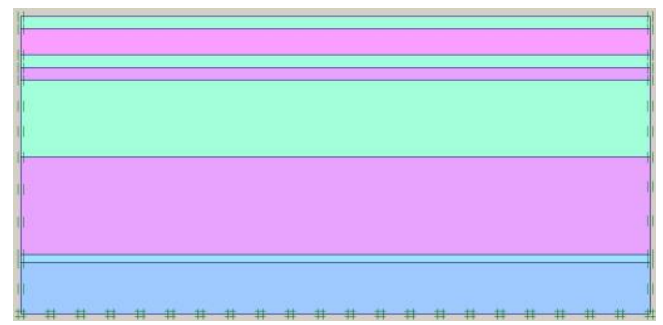

Gambar 12. Cross section tanah 
Tabel 11. Parameter material tanah asli

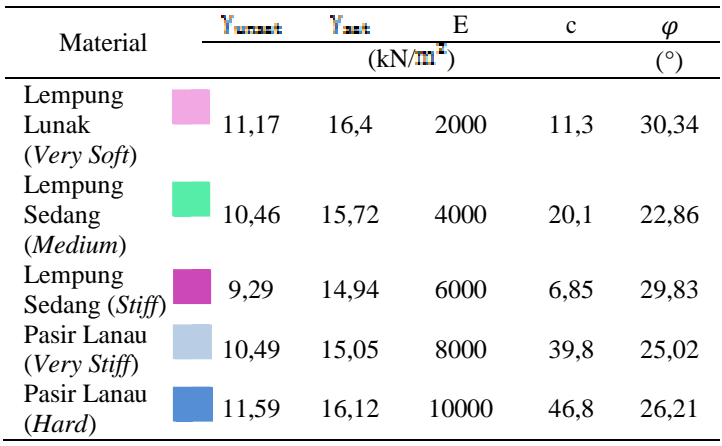

Tabel 12. Parameter material tanah

\begin{tabular}{|c|c|c|c|c|c|}
\hline \multirow{2}{*}{ Material } & Yunan: & $P_{m a t}$ & $\mathrm{E}$ & $\mathrm{c}$ & $\varphi$ \\
\hline & \multicolumn{4}{|c|}{$\left(\mathrm{kN} / \mathrm{m}^{2}\right)$} & $\left({ }^{\circ}\right)$ \\
\hline Timbunan & 18 & 20 & 14000 & 1 & 30 \\
\hline Tanah Stab. & 17,27 & 20,12 & 874.045 & 58,48 & 41,39 \\
\hline
\end{tabular}

\subsubsection{Input Plaxis}

Untuk analisis numeris, dipilih campuran tanah stabilisasi yang memenuhi syarat pengujian kuat tekan tanah untuk lapis pondasi semen komposit tanah. Kemudian campuran tersebut di analisis menggunakan Plaxis V.8.6 dengan berbagai model yang dapat dilihat pada Tabel 13. Diameter (D) kolom dan jarak (s) dari pusat kepusat kolom yang digunakan sebesar $1 \mathrm{~m}$ dengan panjang (L) kolom $10 \mathrm{~m}$, $30 \mathrm{~m}$ dan 50 meter. Penampang kolom dapat dilihat pada Gambar 13. Design pemodelan dapat dilihat pada Gambar 14 dan Gambar 15. Analisis meliputi penurunan di bawah timbunan dan stabilitas timbunan dengan diberi beban sebesar 22,44 $\left(\mathrm{kN} / \mathrm{m}^{2}\right)$.

Tabel 13. Pemodelan analisis

\begin{tabular}{|c|c|c|c|c|c|}
\hline \multirow{3}{*}{$\begin{array}{l}\text { Kadar } \\
\text { Semen }\end{array}$} & \multirow{3}{*}{$\begin{array}{l}\text { Model } \\
\text { Plaxis }\end{array}$} & \multirow{3}{*}{$\begin{array}{c}\text { Tebal } \\
\text { Tanah } \\
\text { Stab. (m) }\end{array}$} & \multicolumn{3}{|c|}{ Kolom } \\
\hline & & & $\mathrm{S}$ & $\mathrm{D}$ & $\mathrm{L}$ \\
\hline & & & \multicolumn{3}{|c|}{$(\mathrm{m})$} \\
\hline \multirow{3}{*}{$7 \%$} & A & - & - & - & - \\
\hline & B & \multirow{2}{*}{$1,3,5$} & - & - & - \\
\hline & $\mathrm{C}$ & & 1 & 1 & $10,30,50$ \\
\hline
\end{tabular}

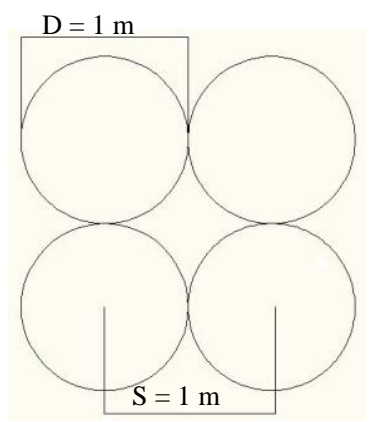

Gambar 13. Pemodelan analisis numeris 2

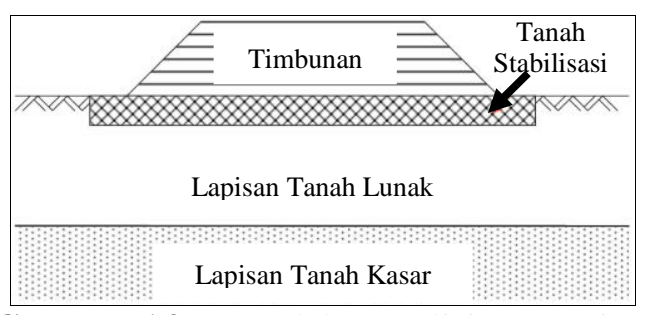

Gambar 14. Pemodelan analisis numeris 1

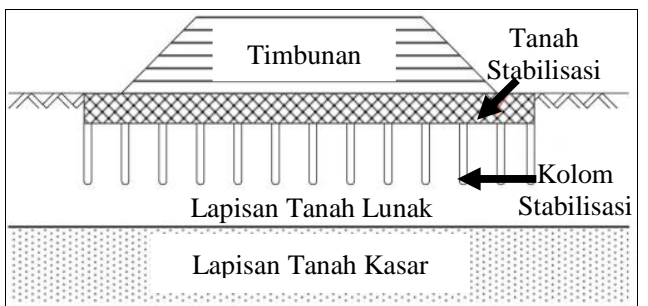

Gambar 15. Pemodelan analisis numeris 2

\subsubsection{Output Plaxis}

\section{Permodelan A}

Pada model A tinjauan dilakukan pada pengaruh tanah terhadap timbunan dan beban. Geometri dapat dilihat pada Gambar 16, deformed mesh pada Gambar 17, total displacements pada Gambar 18 dan vertikal displacements pada Gambar 19.

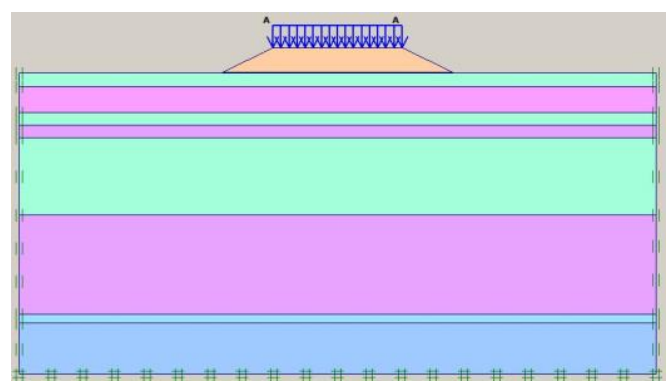

Gambar 16. Geometri model A

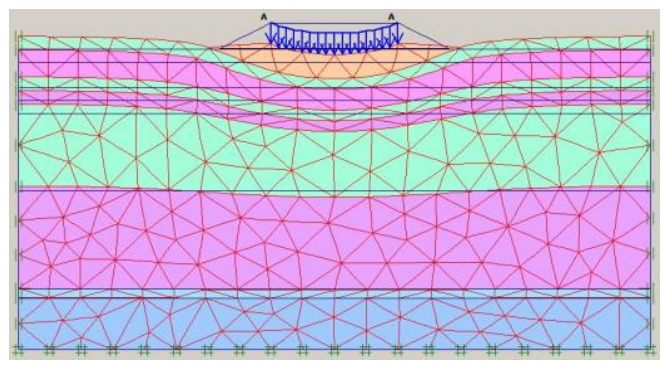

Gambar 17. Deformed mesh model A 


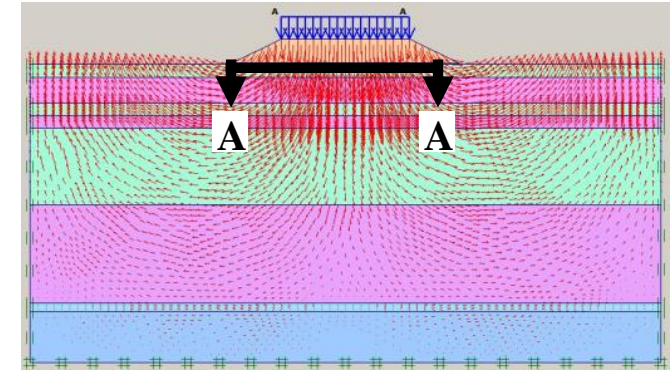

Gambar 18. Total displacements model A

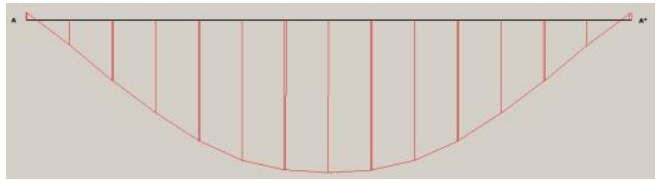

Gambar 19. Vertikal displacements pot. A-A model A

2. Permodelan $B$

Pada model B tinjauan dilakukan pada pengaruh tanah terhadap beban, timbunan dan tebal tanah stabilisasi. Geometri dapat dilihat pada Gambar 20, deformed mesh pada Gambar 21, total displacements pada Gambar 22 dan vertikal displacements pada Gambar 23.

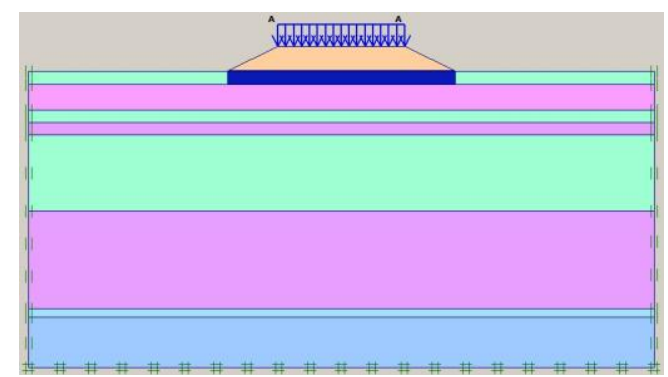

Gambar 20. Geometri model B

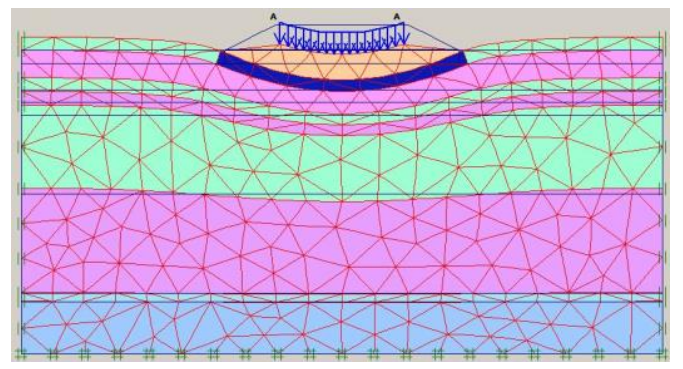

Gambar 21. Deformed mesh model B

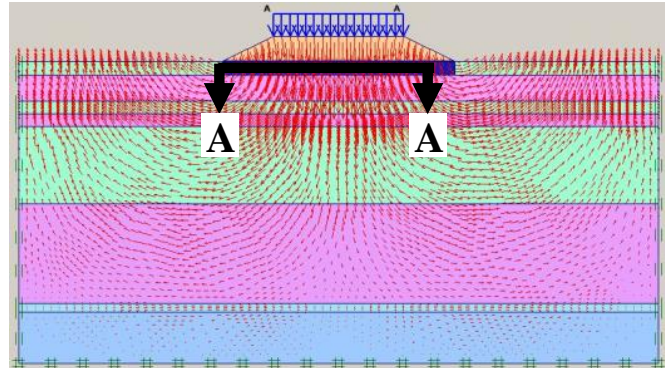

Gambar 22. Total displacements model B

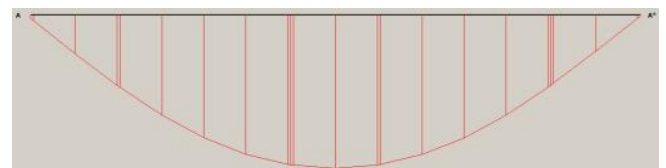

Gambar 23. Vertikal displacements pot. A-A model B

3. Permodelan $\mathrm{C}$

Pada model $\mathrm{C}$ tinjauan dilakukan pada pengaruh tanah terhadap beban, timbunan, tebal tanah stabilisasi dan kolom stabilisasi. Geometri dapat dilihat pada Gambar 24, deformed mesh pada Gambar 25, total displacements pada Gambar 26 dan vertikal displacements pada Gambar 27.

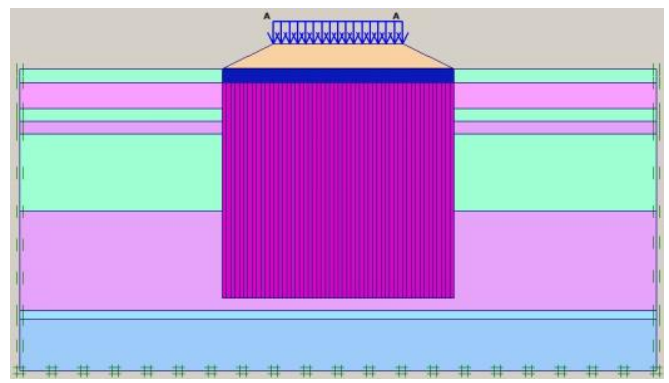

Gambar 24. Geometri model C

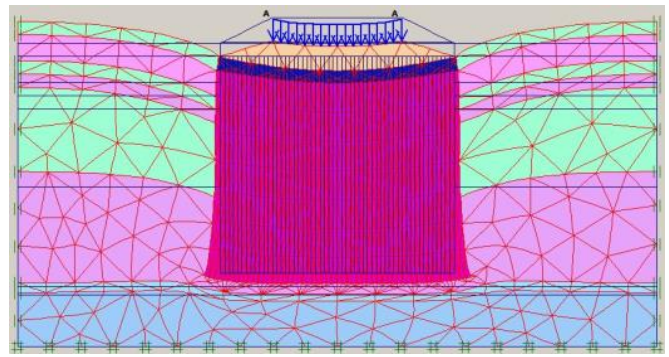

Gambar 25. Deformed mesh model C 


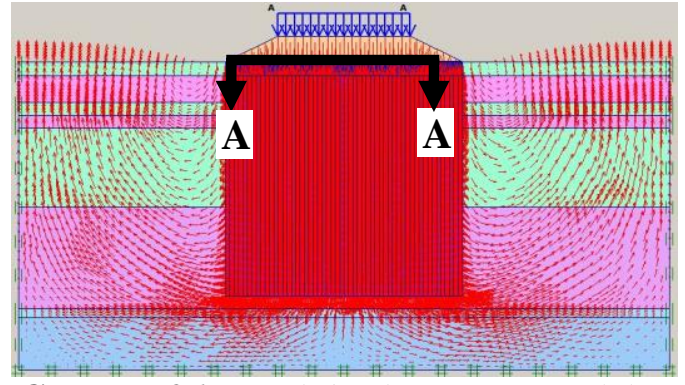

Gambar 26. Total displacements model C

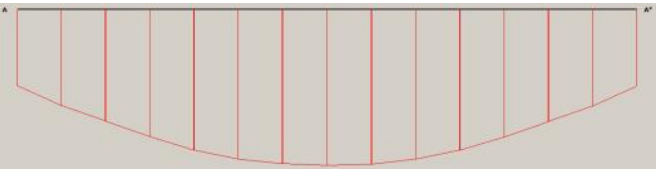

Gambar 27. Vertikal displacements pot. A-A model C

\section{KESIMPULAN DAN SARAN}

\subsection{Kesimpulan}

Kesimpulan dari penelitian ini, yaitu :

1. Pengujian kuat tekan tanah stabilisasi menunjukan peningkatan sampai 41,17 kali dari nilai kuat tekan tanah asli. Peningkatan tidak hanya terjadi pada nilai kuat tekan tanah saja, tetapi pada parameter lain mengalami peningkatan juga. Peningkatan tersebut terjadi karena adanya pengaruh campuran semen dan campuran semen dan bahan aditif.

2. Campuran optimum dari tanah stabilisasi belum memenuhi syarat pengujian kuat tekan tanah untuk lapis pondasi semen komposit tanah yaitu $24 \mathrm{~kg} / \mathrm{cm}^{2}$. Kuat tekan optimum dari tanah stabilisasi adalah sebesar 2,47 kg/cm ${ }^{2}$ dengan campuran semen sebesar $7 \%$ dan bahan aditif.

3. Berdasarkan hasil analisis numeris dengan Plaxis v.8.6, nilai deformasi vertikal (penurunan) permodelan sudah memenuhi batasan penurunan timbunan yaitu $20 \mathrm{~mm}$ untuk jalan kelas 1 dengan nilai faktor keamanan 1,4.

4. Dengan adanya tanah yang distabilisasi dan perkuatan kolom memberikan pengaruh pada nilai deformasi yang terjadi dan kestabilan timbunan. Hal ini ditunjukkan dengan nilai deformasi yang semakin menurun dan faktor aman yang memenuhi syarat. Salat satu hasil analisis pada permodelan yang memenuhi syarat faktor aman dengan nilai deformasi terkecil adalah tanah stabilisasi setinggi $3 \mathrm{~m}$ dan panjang perkuatan kolom $50 \mathrm{~m}$ menunjukkan bahwa nilai faktor aman sebesar 1,4 dengan total displacement sebesar $87,10 \mathrm{~mm}$ dan vertical displacement 7,95 mm. Hasil analisis dapat dilihat pada Tabel 14.

\subsection{Saran}

Adapun saran yang dapat diberikan pada penelitian ini adalah sebagai berikut :

1. Dalam penelitian berikutnya menggunakan model material yang berbeda selain Mohr Coulomb.

Tabel 14. Nilai deformasi dan faktor keamanan stabilitas timbunan jalan

\begin{tabular}{cccc}
\hline Model & Total Displacement $(\mathrm{mm})$ & Vertikal Displacement Pot. A-A $(\mathrm{mm})$ & SF \\
\hline Asli & 205,52 & 31,78 & 1,5 \\
H1 & 206,84 & 31,74 & 1,5 \\
H1K1 & 205,77 & 52,22 & 1,5 \\
H1K2 & 188,50 & 56,00 & 1,5 \\
H1K3 & 111,79 & 11,40 & 1,4 \\
H2 & 206,45 & 24,55 & 1,4 \\
H2K1 & 210,98 & 61,08 & 1,5 \\
H2K2 & 170,53 & 33,27 & 1,3 \\
H2K3 & 99,65 & 9,42 & 1,4 \\
H3 & 193,51 & 22,24 & 1,5 \\
H3K1 & 217,87 & 71,94 & 1,5 \\
H3K2 & 167,35 & 29,22 & 1,3 \\
H3K3 & 87,10 & 7,95 & 1,4 \\
\hline
\end{tabular}




\section{DAFTAR PUSTAKA}

[1]. Suprapto Tm. 2004. Bahan dan Struktur Jalan Raya Edisi Ketiga. Yogyakarta: KMTS FT UGM.

[2]. Hardiyatmo, H. C. 2015. Perancangan Perkerasan Jalan \& Penyelidikan Tanah. Edisi Kedua. Yogyakarta: Gadjah Mada University Press.

[3]. Bowles, J. E. 1984. Sifat-Sifat Fisis dan Geoteknis (Mekanika Tanah) Edisi Kedua. Jakarta: Erlangga.

[4]. Departemen Pekerjaan Umum Direktorat Jenderal Bina Marga. 2016. Lapis Pondasi Semen Komposit (SKh-2.5.4).

[5]. Kitazume, M. dan Terashi, M. 2013. The Deep Mixing Method. London: Taylor \& Francis Group.

[6]. Pusat Litbang Prasarana Transportasi. 2005. Stabilitas Dangkal Tanah Lunak Untuk Konstruksi Timbunan Jalan dengan semen dan cerucuk). Jakarta: Departemen Pekerjaan Umum.
[7]. Karnawati, D. 2005. Geologi Umum dan Teknik. Yogyakarta: Program Pascasarjana Fakultas Teknik UGM.

[8]. Das, B.M. 1993. Mekanika Tanah (PrinsipPrinsip Rekayasa Geoteknis) Jilid 2. Jakarta: Erlangga.

[9]. Hardiyatmo, H. C. 2014. Mekanika Tanah 2 Edisi Kelima. Yogyakarta: Gadjah Mada University Press.

[10]. Amalia, N. 2016. Analisis Stabilitas Lereng Kawasan Pembangunan Pembangkit Listrik Tenaga Mikrohidro Giritirta. Yogyakarta: Departemen Teknik Sipil dan Lingkungan UGM.

[11]. SNI 8460:2017. 2017. Persyaratan perancangan geoteknik. Jakarta: Badan Standardisasi Nasional

[12]. Plaxis 2D Versi 8. 2007. Manual Plaxis. Belanda: Delft University of Technology.

[13]. Rifa'i, A. 2002. Mekanika Kontinum. Yogyakarta: Program Pascasarjana Fakultas Teknik Universitas Gadjah Mada. 